\title{
車椅子の混入が歩行者流に与える影響に関する分析*
}

\section{The Analysis of the Pedestrians Speed of Sidewalk Considering Wheel-chair ${ }^{*}$}

\author{
北川博巳 ${ }^{* *}$, 菅芳樹 ${ }^{* * *}$, 三星昭宏 ${ }^{* * * *}$, 松本直也 ${ }^{* * *}$ \\ By Hiroshi KITAGAWA ${ }^{* *}$, Yoshiki SUGA ${ }^{* * *}$, Akihiro MIHOSHI ${ }^{* * * *}$, Naoya MATSUMOTO ${ }^{* * * *}$
}

\section{1.はじめに}

近年「福祉のまちづくり」に見られるようにこれ まで移動制約者層とされてきた高齢者・障害者に配 慮したまちづくりの概念が各地で見られるようにな った。これまで外出の制限されていた高齢者・障害 者はこれらの対策と生活様式の変化とともに，より ハイモビリティになるものと思われる. 車椅子利用 者も今後はこの方向に向かっており，それに伴い， 従来以上に活力あるまちづくりを構筑してゆく必要 がある. 現在多くの人が車椅子を利用して日常生活 を送っている，車椅子利用者の属性は，肢体不自由 者のみならず，ケガや疾病による体力低下や加齢に 伴う体力の低下のために使用する高齢者などがいる と考えられる. 今後人口の高齢化が進展し, 超高齢 社会を迎えつつある我が国においては，車椅子利用 者は今後増加するものと思われる。しかしながら， 現在車椅子が歩道を通行するときは, 段差のみなら ず，人や自転車に対しての錯綜や歩道上の障害物 等, 決して安全で快適に移動できるような環境とは いえない.

近年，屋外におけるアメニティーを高める方策の 一環として，道路空間の計画や設計の考え方の見直 しが必要とされている段階にある。車いす利用をは じめとする障害者の移動性を考慮した道路対策はそ の中でも重要な課題とされている.

車いす利用者は通常の歩行者とは交通特性の異な

*キーワード : 歩行者交通計画, 交通弱者対策

**正員, 工修, 近畿大学理工学部土木工学科

( 于577 東大阪市小若江 3-4-1,Tet(06)721-2332,Fax(06)730-1320)

***正員，修 (工)，検オリエンタルコンサルタンツ

(干150東京都渋谷区渋谷1-16-14, Tel(03)3409-7551,Fax(06)3409 $-0208)$

****正員, 工博, 近畿大学理工学部土木工学科

( $\bar{T} 577$ 東大阪市小若江 3-4-1.Tel(06)721-2332,Fax(06)730-1320)

*****学生員, 近畿大学大学院工学研究科土木工学専攻

( 5577 東大阪市小若江 3-4-1.Tel(06)721-2332.Fax(06)730-1320)
る交通主体であり，その通行性を高める動きも出て きている．しかしながら，実際の歩道上を対象とし て，車い寸と歩行者が混合した状態で交通流の特性 を把握し，歩道幅員と車い寸・歩行者交通量等と関 連させて通行性の評価をおこない，それにもとづい てサービスレベルを設定するという体系的な研究蓄 積はほとんど無い。この研究の目的ははこのような 背景と問題意識にもとづいて，車いす混合を考慮し た歩道評価と整備技術を研究するものである.

本研究では，一般の歩道を対象として，車椅子を 走行させた場合の歩行者の挙動を把握・分析する. とくに，実際の歩道空間において，車いすが通行し たときのサービスレベルを把握して車椅子が実際の 歩道上を通行するときの影響について考慮すること を目的とする.

ここでは，車椅子が歩道に混入することによっ て, 歩行者の速度分布の違い, 密度との関係にどの 程度の影響があるのかについて分析を行う。そし て，車椅子利用者に対応した歩道を計画，設計する 上での整備のあり方について考察することを目的と している.

\section{2.従来の研究}

近年, 道路構造令で「高齢者, 児童, 身体障害者 等さまざまな人や車椅子等の基本的な諸元をもと に，これらの人が寸れ違い，追い越し，立ち止まる， などの行動が余裕をもつて行えるよう」 ${ }^{1)}$ な道路構 造とする改正が行われている(表-1).ここでは歩行 者の占有幅 $0.75 \mathrm{~m}$, 手動車椅子の幅を $63 \mathrm{~cm}$, 電動車 椅子の幅を $70 \mathrm{~cm}$ とし, 車椅子の通行に必要な幅 (余 裕幅）として，占有幅を $1.00 \mathrm{~m}$ とした。しかし，歩 行者や自転車, 障害物などとのコンフリクトや, 歩 道形態, 人の歩きやすさ, サービスレベルなどは考 
虑されておらず，そのような現実の交通場面を考慮 した基準作りは今後の課題といえる. 車椅子交通の 抱える問題点は多く，実際の歩道において歩行者と のすれ違いなど, 車いす使用者にとって安全で快適 な歩道環境に関する研究は極めて少ない. また, 歩 道に関する研究でも, 自転車と歩行者のすれ違いに ついての問題を考慮しているが，車いすが歩道に混 入したときの車椅子や歩行者に対する影響について は研究がない. 従来, 歩道や歩行者・自転車交通に 関する研究は文献 ${ }^{213)}$ をはじめとして, 多数おこなわ れている. 特徵としては, 歩道幅員を算定した塚口 らの研究 ${ }^{4)}$ 歩行目的別での速度, 密度, 交通量に ついて調查・分析した吉岡らの研究 ${ }^{5)-7)}$, また, 車 道の外側に設置される歩道の最小幅員についての西 坂の研究 ${ }^{8)}$ がある. 細街路においては, 竹内らが, 細街路における歩行者交通空間の確保に関寸る研究 9)をおこない, 歩行者挙動や通行幅員, 通行帯など について分析している.

一方, 車椅子交通については, 屋内での走行分析 や屋内における走行環境について考察したもの, 車 いすの性能に関するもの，施設内等における車い寸 の挙動特性および視覚特性に関するもの, 歩道の段 差に関する調查研究がある ${ }^{10)}$. 車椅子を考慮した歩

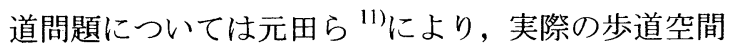
(歩道, 横断歩道, 立体横断施設など) での車椅子自 力走行及び介護走行実験により, 車椅子の一般的な 走行特性と車椅子の利便性, 占有幅などから見た道 路構造についての研究がおこなわれているが, 歩行 者の影響を考慮し, 分析がされていない. また, 車 椅子とのすれ違いなどによる歩行者と車椅子の挙動 について分析しており, 車椅子利用者の注視特性に ついての研究などをおこなっている ${ }^{12) 13)}$. しかし, これらの研究は実際の歩道を対象に調查されておら ず，一般的な歩道における歩行者交通を考慮してい ない.

\section{3.歩道上を車椅子が通行するときの交通特性}

\section{(1)交通実態調查の概要}

本研究では, 車椅子が歩道に混入した場合の歩行者 に対する影響を把握するため，実際の歩道を対象
表-1 道路構造令改正前と改正後の歩道幅員文献1より

\begin{tabular}{|c|c|c|c|c|c|c|}
\hline 区 & 分 & 改 & 正 & 前 & \multicolumn{2}{|c|}{ 改 正 後 } \\
\hline & 位 & \multicolumn{3}{|c|}{$\mathrm{m}$ 以上 } & \multicolumn{2}{|c|}{$\mathrm{m}$ 以上 } \\
\hline \multicolumn{2}{|c|}{ 第 3} & 1.5 & 1.0 & 1.0 & \multicolumn{2}{|c|}{2.0} \\
\hline \multirow{4}{*}{$\begin{array}{l}\text { 第 } \\
4 \\
\text { 種 }\end{array}$} & 第 1 級 & \multirow{2}{*}{3.0} & 2.2 & 1.5 & \multirow{2}{*}{3.5} & 2.75 \\
\hline & 第 2 級 & & 1.5 & \multirow{3}{*}{1.0} & & 2.0 \\
\hline & 第 3 級 & \multirow{2}{*}{1.5} & \multirow{2}{*}{1.0} & & \multirow{2}{*}{\multicolumn{2}{|c|}{2.0}} \\
\hline & 第 4 級 & & & & & \\
\hline
\end{tabular}

として行う。調査地点の選定にあたって, 歩行挙 動に影響を及ぼす要因として, 主要なものは歩道幅 員・地区特性・天候・障害物等の条件が考えられる が，これらのすべての組み合わせに対して十分なデ 一夕を確保することはいくつかの制約もある．なる ベく多くの調查地点をカバーするため, 大阪府下の 鉄道駅周辺の歩道 11 地点において, 時間帯, 歩道幅 員, 歩行者交通量の異なる場所を選定し, 歩道に車 椅子が混入した場合と混入しなかった場合と場合に 分け，家庭用 VTRにより走行実験調査を行った.な お, 歩行者の挙動をなるべく多くカバーするため, 6 地点は過去の研究 ${ }^{16)}$ により調査した地点とした。ま た，歩行者が比較的高密度となるような地点を選定 し，幅員は 1.6〜4.5メートルとばらついた. 一方, 車椅子を混入させた歩道は幅員が $3.5 \mathrm{~m} \sim 4.5 \mathrm{~m}$ と比 較的広幅員な歩道を選定した。 それぞれの地点の幅 員と概要を表-2 に示す.

これらの地点は歩行者の挙動がよくわかるような 地点とし, 歩行者交通量のなるべく多い地点を考慮 した. 歩道幅員は表-2 の地点 $\mathrm{A} \sim \mathrm{G}$ である. 今回, 車椅子が混入した場合の速度，密度などの分析をす るにあたっては, 5 地点を選定した. 調査場所を決 定するに際しては，車椅子を混入させる際につぎの 要因が分析に影響を及ぼすと考えられ，つぎの 4 項 目を考慮した上で，表-2 の $\mathrm{H} \sim \mathrm{K}$ に示す地点を取り 上げた。 


\begin{tabular}{|c|c|c|c|c|c|c|}
\hline 調 査 場 所 & \multicolumn{3}{|c|}{ 調 査 日 } & \multicolumn{2}{|c|}{ 調査時間帯歩道幅員 } & 備 \\
\hline A. 和 泉 市 & H. 4 & 11 月 & (日曜日) & 朝・昼·夕 & $2.2 \mathrm{~m}$ & 店舗周辺（和泉府中駅） \\
\hline B. 東大阪市 & H. 4 & 11月 & (日曜日) & 朝・昼・夕 & $3.2 \mathrm{~m}$ & 店舗周辺（八戸ノ里駅） \\
\hline C. 大阪 市 & H. 5 & 9 月 & （日曜日） & 昼·夕 & $4.5 \mathrm{~m}$ & （難波） \\
\hline D. 八尾市 & H. 5 & 9 月 & （木曜日） & 朝・夕 & $2.6 \mathrm{~m}$ & 店舗周辺（近鉄八尾駅） \\
\hline E. 柏 原 市 & H. 5 & 9 月 & （金曜日） & 朝・夕 & 2. $4 \mathrm{~m}$ & （近鉄国分駅） \\
\hline F. 東大阪市 & H. 5 & 9 月 & (金曜日) & 夕 & $1.6 \mathrm{~m}$ & （近鉄八戸口里駅） \\
\hline G. 明 石 市 & H. 6 & 10 月 & （木曜日） & 8 & $3.4 m$ & （明石駅） \\
\hline H. 明 石 市 & H. & 10 月 & (月曜日) & 夕 & $3.4 m$ & (明石駅) \\
\hline 1. 大東市 & H. & 8 月 & (日曜日) & 8 & $4.5 \mathrm{~m}$ & （JR住道駅） \\
\hline J. 東大阪市 & H. & 7 月 & (金曜日) & 朝 & $3.25 \mathrm{~m}$ & （近畿大学前） \\
\hline K. 大 阪 市 & H. & 11 月 & （木曜日） & 朝 & 4. $0 \mathrm{~m}$ & （御堂筋） \\
\hline
\end{tabular}

(1)本研究では，歩行者と車椅子との影響を把握す るため自転車交通を考虑していない。したがっ て自転車の琵人の少ない地点とした。

(2)路上の障害物による回避行動を排除寸るため, 路上の障㫪物がない地点

(3)分析刘象となる步行者が途中で歩行行動を止め

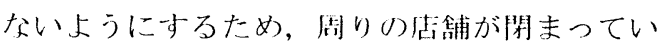
ろか，ない地点

(4)車椅子が混人寸万と比較的㹨い幅員の歩道でに 抢いては，歩行者は減速せずに歩道外にでて歩行 することが考えられる，今回，車椅子を交通させ るに当たっては，3〜 4m 程度の幅員の歩道を対象 とした.

な㧍、VTRによる撮影は車椅子混入時，非混入時 ともに 15 分間，対象区間長は $10 \mathrm{~m}$ とした。撮影に 関寸万注意点としては，以下の 3 項目を考虑した上 で相椅子を混入させ，撮影を行った。

(1回避行動を把握す万ための距離として，分析対 象区間を $10 \mathrm{~m}$ とした。そのため，全域をビデオ 画而でとらえられるようにカメラを設置する。

(2)愉子の走行に䦥しては，原則的に少道の中央

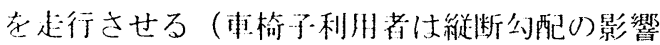

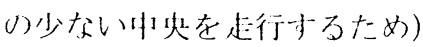

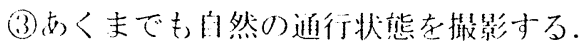

(2)車椅子が混入するときの歩行者速度の分布

一般的な步行者の平均歩行速度は $1.35 \mathrm{~m} / \mathrm{s}$ となっ ているが，本研究で扔こなった雕榃データより車椅 子が混人していない場合（以下，車椅子非混入時ま たは非混入時）の歩行者の平均速度は $1.23 \mathrm{~m} / \mathrm{s}$ と低 い伹であった（補注 1)。また，本研究ではできるだ け多くの調查地点とサンブル数老增や寸ため，また 車榆子混入時は幅員の広い步道を対象としているた め, 各地点間ごとに歩行者挙動を分析寸るよりは, 大きく混入・非混入の 2 つに分割し分析するアプロ 一チを取っているため, それぞれ歩行者速度を1つ にまとめて分析している.

ここでは図-1図-2より，車椅子が混入していない 時，車椅子が混入した時の歩行者の交通特性につい て, 歩行速度, 密度から分析を㧍こない, 車椅子混 入時に扔ける歩行者速度の低下摔をもとめた。車椅 子非混入時の歩行者速度は, 步行速度分布（図-3） は值の小さい方に裙広がりな分布をして抢り最大值 $1.94 \mathrm{~m} / \mathrm{s}$, 最小值 $0.54 \mathrm{~m} / \mathrm{s}$ と分布範四は広いが，極め て少数であり, 歩行者の多数は秒速 $1.0 \sim 1.4 \mathrm{~m} / \mathrm{s}$ が 多くを占めていることもあり，分散は 0.056 と低い， 調查したどの歩道に执いても，州椅子非混入時に打 いては步行者速度のばらつきは小さく，一定速度で の近行となっている倾问にある。同栚に，相椅子混

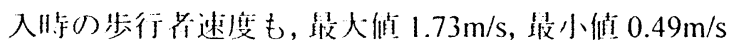

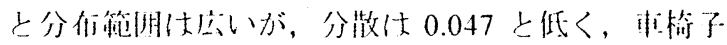


混入時と间栚, ばらつきは小さい. 少行速度分布（図 -4）は非混入時同様，值の小さい方に裙公がりな分 布をして扝り, 歩行者速度のばらつきも小さいこと がわかる。これらより, 東椅子混入時と非混入時で は歩道幅員に違いがあるものの，今回対象とした歩 道区間に関しては，速度分布心傾向が似ている。一 蔇には言えないが，今回選定した調査地点は車椅子 を混入させた場合で幅員は広くなっており，歩行者 に対する影響が著しいものでないため, 歩行者速度 の分布の観点では，車椅子混人・非混入時ともに似 たような倾向になっていると想われる。

\section{(3)車椅子が混入する時の歩行者速度の低下}

今回調査した地点では少道幅員に違いがあるもの の，速度分布という観点では似た傾向となってい る。そこでここでは，畃椅子が混人した皓の步行 者一の影響を速度分死だけでなく，速度の低下はそ の歩道のサービスレベルの低下を促寸主たる数因の 一つであることより，本揄子が混人寸ることの速度 低下に着目し，東榆子が少道に混人することにより 歩行速度にはどれくらいの影唶について考察する。

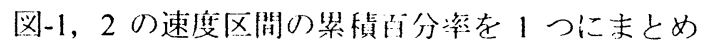
たものを図-3に示寸。この図から，速度区間 $0.7 〜$ $1.4 \mathrm{~m} / \mathrm{s}$ 間で分布に開きがみられる。これは, 各地点 での幅員が違っているものの，分布の公がりとばら つきの少なさおよび，車椅子混入時の幅員が広いこ とも考虑すると，車椅子が混入することにより，歩 行者の速度が低下寸ること示している，その低下 の割合をみると，最大で約 $0.3 \mathrm{~m} / \mathrm{s}$ 低下している.

このことより，歩行者分们の傾问が似ているにも かかわらず，速度低下がみられるということより， 車椅子が混入することによる歩行者速度の低下率を 計算することを試みる。そのため，車椅子非混入時 と混入時の速度の分布が闹じかどうかを検定した。 ここでは，繰り返しのない一元配置の分散分析をし た。これより，この二つの分有に差を留如られない という結果が得られることになり，本椅子混入時の 歩道幅員の違いから，速度分布は等しく，速度低下 とひ関倸も间じと䍐われる。しかし，西椅子混人時

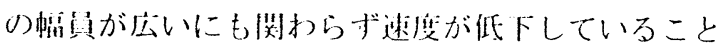

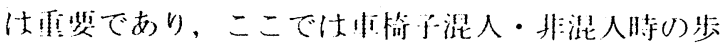

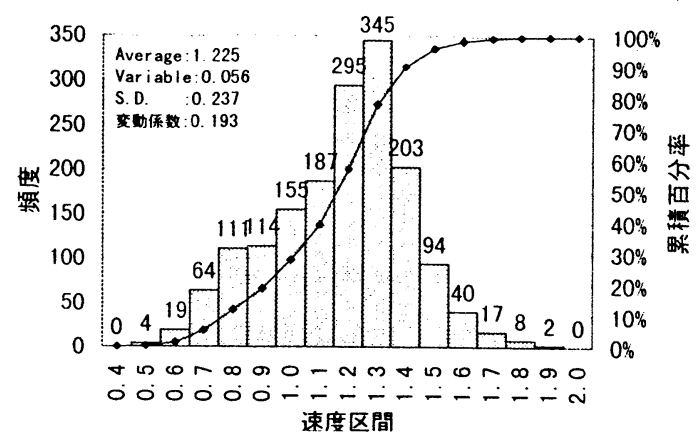

図-3 歩行者速度分布図（車掎子非混入時）

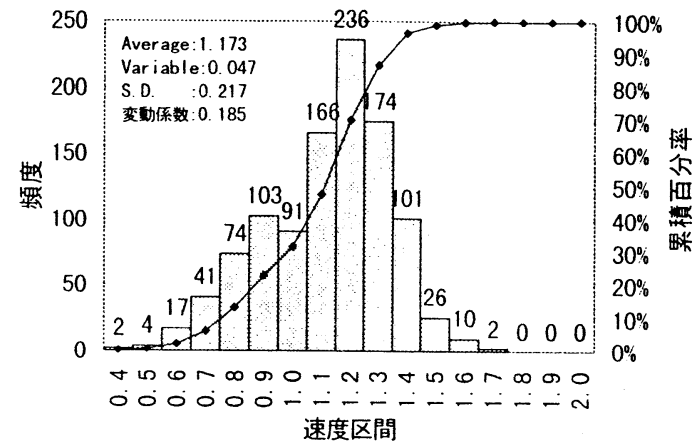

図 4 歩行者速度分布図(車椅子混入時)

表 4 歩行者速度の母平均の推定

\begin{tabular}{|c|c|c|c|c|c|}
\hline & 件数 & 下限値 & 平均 & 上限値 & 信頼区間 \\
\hline 非混入時 & 1658 & $1.21 \mathrm{~m} / \mathrm{s}$ & $1.23 \mathrm{~m} / \mathrm{s}$ & $1.24 \mathrm{~m} / \mathrm{s}$ & $95 \%$ \\
\hline 混入 時 & 1047 & $1.16 \mathrm{~m} / \mathrm{s}$ & $1.17 \mathrm{~m} / \mathrm{s}$ & $1.19 \mathrm{~m} / \mathrm{s}$ & $95 \%$ \\
\hline 割合 & - & $-4.4 \%$ & $-4.3 \%$ & $-4.1 \%$ & - \\
\hline
\end{tabular}

行者速度を推定し, 比較を行う。このとき, 調查 デー夕はその量, 質により変化するため, この調査 データから単純に低下率を計算するよりも，本研究

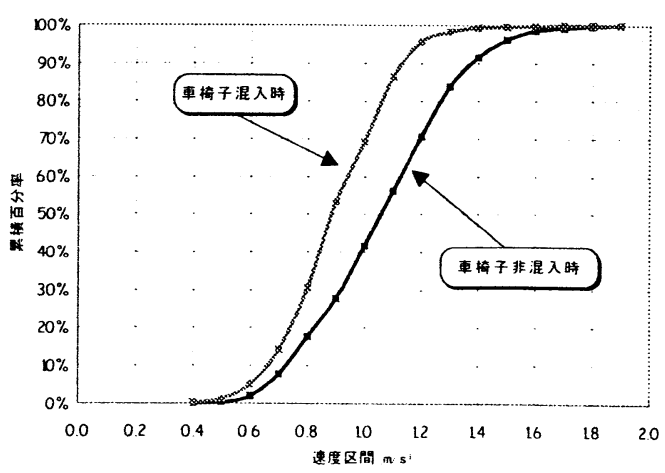

図 5 歩行者速度分布図（車椅子混入時） 
では, 車椅子非混入時, 混入時の母平均を区間推定 し，その推定結果より低下率を求めた。その結果を 表-4 に示寸。この表より車椅子が混入することによ り歩行者の平均速度では約 4.3\%低下しているが, 上 限値・下限值においてもそれぞれ $4.1 ， 4.4 \%$ 速度が 低下している。このことより，車椅子が混入するこ とにより, 歩行者速度は低下し, 歩行者にとって影 響があることがわかる。

つぎに，通常，歩行者速度は密度と関係があるも のと思われる。ここでは, 歩行速度と密度の関係に ついて分析をおこなった。まず, 速度, 密度間の相 関係数を求めた。相関係数の求め方は各種研究され ているが,ここでは Person, Kendall のタウ, Spearman の 3 つの方法により求めた（表 5). 車椅子非混入, 混入時ともに相関係数の值は小さく, 密度-速度間に 相関はないように思える。また，一般には歩行速度 と密度の間には負の相関があることが知られている が，本研究での分析では柆椅子混入時では值は小さ いものの，正の相関が認められた。つぎに，図-6に 䡮椅子非混入時の, 図-7に相椅子混入時の速度一密 度敬有闵をそれぞれ示寸。今间設定した調查地点の データをそれぞれ，同一にまとめて分析しているた め, 各密度区間における歩行者速度のばらつきは大 きいものとなった。そこで, 速度一密度に関しては 各調查地点ごとに速度一密度に関する回帰直線を算 出し，比較した。表より，それぞれの地点に执いて， 淔線の傾き・切片は違っており, 幅員と傾き・幅員 と切片の相関関係が高くなっていることから, 地点 ごとに考察する．全体として車椅子混入時の場合は 傾きが低くなっている，また，切片は多くなってい る. 剉片については車椅子が混入時の歩道は幅員が 大きいため，低密度の場合は速度も大きくなるため に、このように多くなっている，一方，傾きは密度 が大きくなるほど速度が低下寸ることを示してお り，たとえ相榆子非混人時より，幅是が広くても車 椅子が混入寸ると速度低下に影響寸るものと思われ 3 .

こいように，今回密度に閉寸る閉係としてこのよ うにげらつきが多くなった原团としては低湾度での

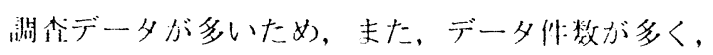

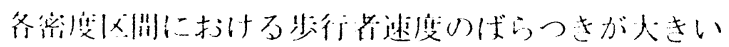

ため, また，実際の歩道での調査でのデー夕を用い ているため, という事が考えられる。 また，速度一 密度に関してもサンプル数が少なくなるため, 若干 の問題は残っている.

\section{5.まとめ}

本研究は今後增加すると考えられる車椅子交通が実 際の歩道にどれくらいの影響を及ぼしているのかに ついて，実際の歩道を対象としたVTR を用いた害 態調査から車椅子が歩行者速度にどのような影響を 及ぼしているのかについて, 歩行者速度の分布・歩 行者速度の低下および歩行者速度と密度との関係か ら分析を行っ

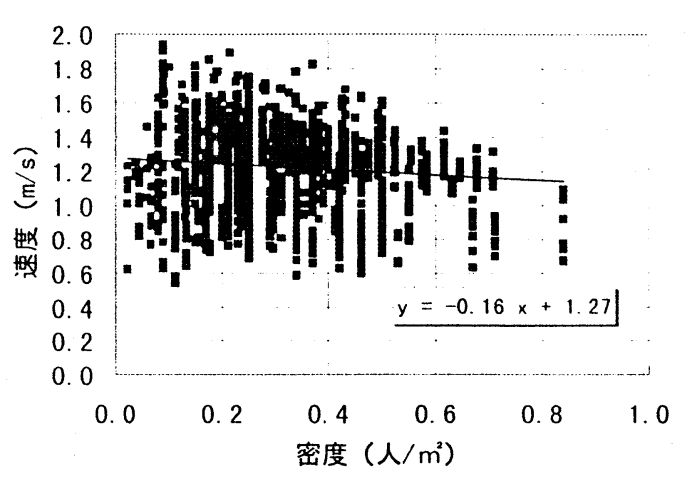

図 6 歩行者速度分布図（車椅子混入時）

た. 結果としては, 以下のようになった。

(1)実際の歩道に車椅子を走行させたときの実態調査 を実施した。車椅子混入時と車椅子非鼬入時の幅 員に違いがあるものの，11 地点を選定し，比較を 行った。

(2)車椅子混入時と非混入時の速度分布を集計したと ころ, 分布に関する差はほとんどみられなかっ た。歩行速度分布という観点からは，車椅子を混 入させた歩道はさほど歩行者に対する影響は著し くなく，今回観测した歩道幅員程度は必要なもの であると無えられる。

(3)步行者速度の低下という锶点からみる上，歩道を 相榆了が近行寸ることにより，最大で $0.3 \mathrm{~m} / \mathrm{s}$ の低 卜が欢られ，步行者の速度を推定した綃果，車椅 
表-5 齐テ法による相関係数の比較

\begin{tabular}{c||c|c}
\hline $\begin{array}{c}\text { Correlation } \\
\text { Coefficients }\end{array}$ & $\begin{array}{c}\text { 車椅子 } \\
\text { 非混入時 }\end{array}$ & $\begin{array}{c}\text { 車椅子 } \\
\text { 混入時 }\end{array}$ \\
\hline \hline Pearson & -0.10 & 0.04 \\
Kendall's & -0.07 & -0.01 \\
Spearman & -0.09 & 0.02 \\
\hline
\end{tabular}

(3)下がみられ，歩行者の速度を推定した結果，車椅 子が混入すること平均速度が $4.3 \%$ 低下すること がわかった。

(4)歩行者速度一密度からのアプローチにおいて, 各 测定地点をひとつにまとめて考察することは好ま しくないことがわかり, 地点ごとの速度一密度の 回帰式を算定した。その結果，車椅子が混入した 場合の傾きは非混入晾のそれよりも低くなり，幅 員が㳂くても車椅子混人による速度低下の影響が 女る。

また，今回の調查地点の少道幅員である 3.25〜 $4.5 \mathrm{~m}$ の間では車椅子利用者の立場に立つと，自転車 や障害物等が混入すると，过榆子が快適に走行でき るような幅員といえず，安全・快適・利便性の良い 歩道幅員の考察も必要となってくる. 今後の課題と しては，さらに雑多である步道をカバーする意味 で, 種々の条件の違う箇所でのデータの蓄樍や調查 サンプルを增やす必要がある．とくに，幅員の影響 の詳細に関しては今後の課題である。また生活様 式の変化により, 今後は車椅子利朋者が連れ立って

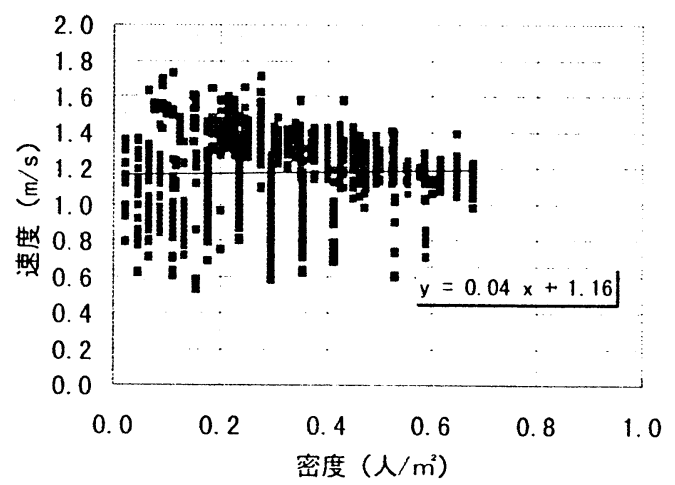

図 7 歩行者速度分布図（車椅子混入時）

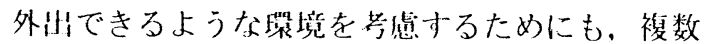
古の目椅子を志行させ，分析してゆきたい。また，
サービスレベルを一䇥に保つ歩道幅員算定のため に，歩道に扔ける諸条件を変数としたシミュレーシ ヨンの棈筑なども行ってゆきたい。

\section{（補注）}

步行者の平均速度が $1.35 \mathrm{~m} / \mathrm{s}$ という值は小学生や中 学生なども含まれており, 本研究でのデータにはこ のような青年以下のデータは少なく, また, 歩行者 の歩行速度はその条件や調査日時などにより変化す るため, 本研究ではこの $1.23 \mathrm{~m} / \mathrm{s}$ という平均速度は 妥当だとしている.

\section{参考文献}

1)佐藤信彦: 道路構造令などの改正について, 道路, pp.44-53, 1994-1

2)Fruin, J.J. : Design for Pedestrians;A level-of-service concept, Highway research record, No.355, 1971.

3)Navin, F.P.D., R.J.Wheelse : Pedestrian Flow Characteristics, Traffic engineering, 39, 9, p.30, 1969.

4)堟门愽闹：歩行者交通空閆の計画に関する基礎的 研究, 昭和 56 年, 大阪大学博士論文

5)吉阔昭雄: 歩行者交通と歩行者空間 (I), 交通工

学, Vol.4, PP.25-36, 1978

6)吉掽昭雄: 歩行者交通と歩行者空間（II）, 交通工

学, Vol.5, PP.41-53, 1978

7)吉岡昭雄 : 歩行者交通と歩行者空間（III）, 交通工 学, Vol.3, PP.13-21, 1981

8)西坂秀博: 歩道の最小幅員に関する研究, 交通工

学, 增刊号, pp.3-15, 1978

9)竹内伝史, 岩本広久: 細街路における歩行者挙動 の分析，交通工学，Vol.4，pp.3-14，1975

10)たとえば，日本リハビリテーション工学協会 : 第 11 回リ八工学カンファレンス講演論文集, 1996.

11)元间良孝, 西阔南海男: 車椅子の走行特性と道路 構造について，交通工学，Vol.24，No.6, pp.2130,1989

12)浮水浩志郎：高㱓者の注視特性を考虑した快適な 歩行睘境整供に関寸る研究, 平成 6 年度科学研 究费神助金[一般研究(B)]研究成果報告青, 1995 